\title{
DISEASE AS AGGRESSION IN THE HIPPOCRATIC CORPUS AND GREEK TRAGEDY: WILD AND DEVOURING DISEASE
}

It is well known that the rational understanding of disease that we find in the Hippocratic Corpus contrasts with a much older conception that is represented in Greek tragedy. Since the subjects of Greek tragedy are mythical, the belief in the divine origin of disease is widespread, and the important healing figures are gods. By contrast, Hippocratic doctors explain disease by natural causes and reject any intervention of an anthropomorphic divinity; and their therapeutic action combats the cause of the disease through rational means.

Although the understandings of disease in medical literature and in tragedy are clearly far apart, a more detailed investigation reveals similarities as well as differences. To show these similarities, two methods of investigation present themselves. The first is to demonstrate how the rational understanding of doctors managed to influence the tragic authors. ${ }^{1}$ The second has been much less explored and will form the basis of this paper. It consists in showing that in spite of its prevailing rationalism, the Hippocratic Corpus' vocabulary of pathology preserves, in what is usually called its metaphorical expression, traces of an older representation of disease, similar to that used in tragedy. It is the understanding of disease as an aggressive force that attacks the individual from the outside, penetrates him, takes possession of him and, like a wild animal, can feed on his flesh. The philologist that adopts this approach must list and semantically analyse the entire metaphoric vocabulary of disease, both in the Hippocratic Corpus and in tragedy, in order to reconstruct its force and coherence and to clarify the image of disease it contains. Since a full comparison is not possible within the constraints of this paper, I will limit myself to the specific theme of the vocabulary of wildness and devouring. The first part of the paper will study

${ }^{1}$ I adopted this approach in "Médecine hippocratique et tragédie grecque," in P. Ghiron Bistagne and B. Schouler, Anthropologie et théâtre antique: actes du Colloque international de Montpellier 6-8 mars 1986 (Cahiers du Gita III) (Montpellier 1987), pp. 109-131, also included in the present volume (see ch. 4).

This is an open access chapter distributed under the terms of the CC-BY-NC License. 
wild disease in general; the second part, a particular aspect of this wild disease, namely the devouring disease. Each part will begin with tragedy before moving on to the Hippocratic Corpus.

In Greek tragedy, disease is often associated with savagery. Indeed, the adjective "̈rpros, 'wild', to describe pathological phenomena appears in the work of the three tragedians. In Aeschylus' Choephori, Orestes, recalling the dreadful diseases that Apollo's oracle promised in punishment if he does not avenge the death of his father, speaks of "ulcers with a wild bite" (28o ff.:

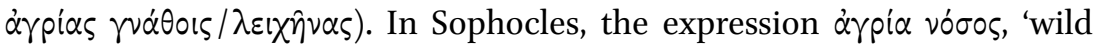
disease', is found in two tragedies: concerning Heracles, in the Trachiniae, beset by a new bout of pain caused by the poisoned tunic given to him by Deianeira, we find: "there leaps again ... the wild disease" (v. 1026 and 1030:

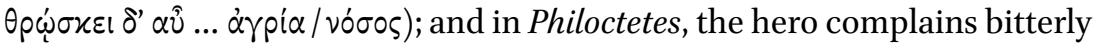
to Neoptolemus for having been abandoned whilst he was consumed by the effect of a wild disease ( $265 \mathrm{ff.:} \alpha \gamma \gamma p i \alpha / v o ́ \sigma \omega)$. Finally, in Euripides' Orestes, performed the year after Sophocles' Philoctetes, the same expression $\alpha \gamma$ pi $\alpha$ vóros, 'wild disease', is used by Electra in the prologue to describe the illness that has taken hold of Orestes after the death of his mother. She says in lines 34ff:: "After this, poor Orestes fell ill, consumed by a wild disease"

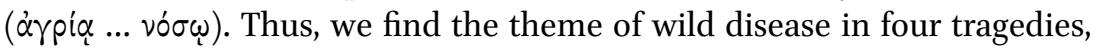
written by three separate tragedians, that were staged within half a century of each other, from 458 (the date of Aeschylus' Choephori) to 408 (the date of Euripides' Orestes). It is remarkable that the influence of rational medicine, which is most perceptible in the tragedies towards the end of the century, does not lead to a decline in the conception of wild disease. On the contrary, it is in the two more recent tragedies, Sophocles' Philoctetes of 409 and Euripides' Orestes of 408, that the theme of wild disease is most extensive and recurring. In these two tragedies, not only is disease wild, but the patient has a wild aspect as well. The same vocabulary is applied to both the patient and the disease; it is the verb $\dot{\alpha} \gamma p$ ió $\omega$, from $\alpha \dot{\gamma} p 10 \varsigma$, that is used in the passive perfect to describe the wild aspect of the hero, either in its simple form

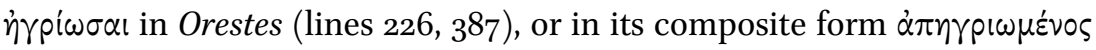
in Philoctetes (line 226). ${ }^{2}$

${ }^{2}$ However, we should add that in Sophocles' Philoctetes, the hero's feralisation is explained not only by his disease, but also because he lives in the company of wild beasts (cf. lines $184 \mathrm{ff}$.). In Euripides' Orestes, the relationship between the wild character of the disease and the wild state of the patient is more direct, but is expressed in a rational form: the patient's wild aspect arises from the fact that the disease has prevented him from washing (cf. 226). The similarity of the use of the vocabulary of the wild in Euripides' Orestes and 
The representation of wild disease is less widespread in the Hippocratic Corpus than in tragedy, but its presence is stronger than we might think. Of course, we must distinguish within the Hippocratic Corpus between the technical writings and the Letters. Let us begin with a passage from the Letters, which combines the two adjectives that we find in the Hippocratic Corpus to mean 'wild disease'. In Letter 2, the apocryphal author describes the diseases treated by Hippocrates as 'beastly and wild' (9.314,16 ff. L. =

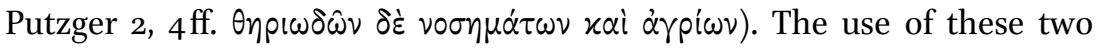
adjectives is justified by the context: Hippocrates the doctor, who rids the earth and sea of beastly and wild diseases, is compared to Heracles, who rid the world of wild beasts. This comparison refers to a reality of the Roman era: Pliny the Elder tells us that the deified Hippocrates received the same honours as Heracles, ${ }^{3}$ and this is confirmed by a coin from Cos, preserved in the numismatic collection of the National Library of Paris (no. 1246), which bears an image on its front of Heracles with his club, and on the reverse side a portrait of Hippocrates. This conception of the doctor purging beastly and wild diseases, although current in the Roman period, comes from a much older conception of the doctor that is found in Greek tragedy: we know that the doctor Apis, in Aeschylus' Suppliants, purged the land of Argos of maneating monsters (line 264).

In the technical writings of the Hippocratic Corpus, we do not find the

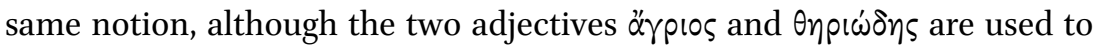
describe pathological phenomenona. The adjective $\ddot{\alpha} \gamma p$ los appears twice: in Epidemics 7, ch. 20 (5.392,8 L.), it describes an inflammation: Ctesiphon, suffering from dropsy following severe causus, developed a swelling on his

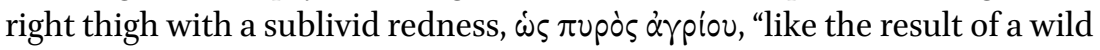
inflammation." According to Galen's Hippocratic Glossary (19.134,2 K.), this wild inflammation was erysipelas. Elsewhere, in the Diseases of Women 1 , ch. 8 (8. 38,3-4 L.), it describes certain ulcers: $\varepsilon^{\lambda} \lambda \varepsilon \varepsilon \alpha$... $\dot{\alpha} \gamma p i \omega \dot{\tau} \tau \rho \alpha$. We may add to this the use of the verb àpiów that we find in Airs, Waters, Places, ch. 4, also regarding ulcers that do not become wild $(2.20,17 \mathrm{~L}$. $=$ Diller

Sophocles' Philoctetes suggests that Euripides had Philoctetes' disease in mind and wanted to compete with Sophocles in representing the scene of the disease's crisis (cf. M.L. West, Euripides, Orestes (Warminster, 1987), beginning at lines 34-35 and 226, and Introduction, p. 32). On the wild in the Orestes, see P.N. Boutler, "The theme of AGRIA in Euripides 'Orestes', ," Phoenix 16 (1962), 102-106.

${ }_{3}$ Pliny the Elder, Hist. nat. 7 , ch. 37, (123): "Hippocratis medicina, qui venientem ab Illyriis pestilentiam praedixit discipulosque ad auxiliandum circa urbes dimisit quod ob meritum honores illi quos Herculi decrivit Graecia." 
p. 30,19 ovं $\dot{\varepsilon} \dot{\alpha} \gamma p 10 v 0 \theta \alpha \mathrm{l})$. This last passage is particularly important because it shows that, although in a rational context, the original sense of 'wild' is still carefully chosen. It concerns a rational context, since this mention of ulcers is situated in the nosologic outline of cities that are orientated towards the northern winds. Nevertheless, the author deliberately brings out the original meaning of $\alpha \gamma p 10 \hat{\sigma} \sigma \theta \alpha$, since he compares and contrasts in two adjoining

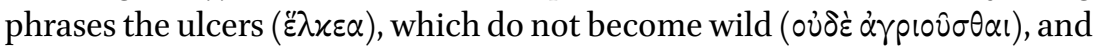

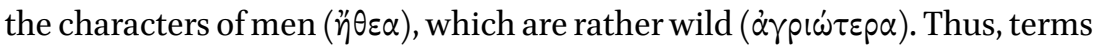
related to $\ddot{\alpha} \gamma p$ ios can apply equally well to both diseases and men in the Hippocratic Corpus. ${ }^{4}$

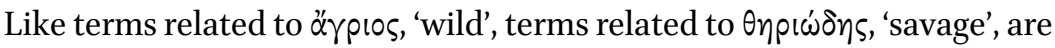
attested in the Hippocratic Corpus to describe pathological phenomena.

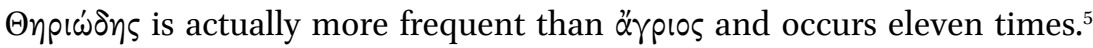
The adjective can describe a pathological state where either the patient or the disease, or both at the same time, fly into a rage, literally like a wild

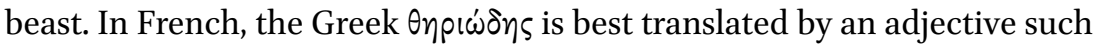
as 'férin', since this technical medical term (meaning 'agitated, troubled'), derived from Latin ferinus, 'wild', and ultimately from fera, 'wild beast', can be traced back to the same Indo-European root (*ghwer-) as the adjective өnpí́ons. For example, in Prorrhetic 1, ch. 26 (5.516, 9 L.= Polack 77, 16 ff.), we read that some "short-lived and bold madness comes from a 'ferine'

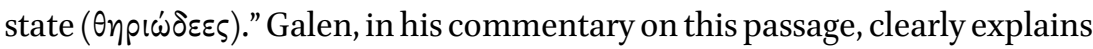
what is meant. It is an acute form of delirium, where "the patients thrash their feet, attack, bite, are crazy, believe that anyone who approaches them wishes to harm them." ${ }^{\prime 6}$ The neuter noun inpiov, from which the adjective

${ }^{4}$ Terms related to $\ddot{\gamma} \gamma p$ both patients and diseases. For example, Aretaeus uses the verb àp phrenetics who display wild behaviour and are delirious (Treatment of Acute Diseases 1, ch. 1, 3 , ed. Hude ${ }^{2} 92,4$ ), or to refer to grazing ulcers that become enflamed and wild (The Causes and Signs of Chronic Diseases 2, ch. 11, 4 and 7, ed. Hude ${ }^{2}$ CMG II, p. 80,23 and 81,16ff.).

5 The adjective $\theta \eta p$ grouped in Epidemics 2-4-6 (Epid. 2.1, ch. 3; 5.72,12 L.; Epid. 4, ch. 16, 5.154,12 L.; Epid. 6.1, ch. 11, 5.272,1 L.; 6.2, ch. 6, 5.280,5 L.; 6.2, ch. 11, 5.282,16 L.), in Prorrhetic 1 (ch. 26, 5.516,9 L.; ch. 123, 5.552,6 L. ff.) and in Coan Prenotions (ch. 84, 5.602,5 L.; ch. 151, 5.616,6 L.; ch. 241, 5.636,14 L.; ch. $613,5.726,17 \mathrm{~L}$.). In these eleven occurrences, there are a number of parallel passages. All the passages in the Prorrhetic 1 and Coan Prenotions, with the exception of Prenotion 613, are comparable, since they concern the same case of delirium. The passages from Epidemics 24-6 are divided into two groups: 1.) the relationship between Enpíions and the autumn (Epid. 2.1, ch. 3; Epid. 4, ch. 16; Epid. 6.1, ch. 11); 2.) the use of Anpicíns in relation to a cough (Epid. 6.2 , ch. 6 and 11$)$.

${ }^{6}$ Galen, On Hippocrates' Prorrhetic 1.25, ed. Diels CMG V 9, 2, p. 39. 


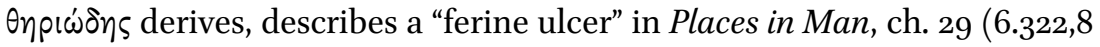
L.= Joly 64,24). Galen, in his Hippocratic Glossary (19.103,12 K.) glosses Anpíov

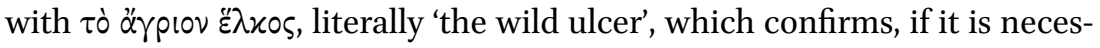
sary at all, the proximity of usage of these two families of words to describe a disease's wild behaviour. ${ }^{7}$

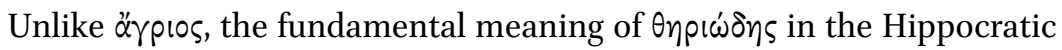
Corpus has been obscured by a particular meaning suggested by commentators in antiquity who, as the glosses of Erotian and Galen clearly show, ${ }^{8}$

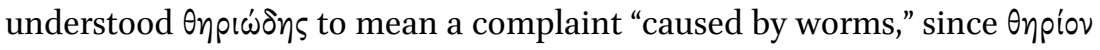
can also mean 'worm'. ${ }^{9}$ This interpretation has had considerable success in modern scholarship. In eleven instances of the term Өnpicions where the meaning is debatable, Littré chose six times the meaning 'caused by worms', and only five times the fundamental meaning of 'savage'. ${ }^{10}$ Since modern editors tend to follow in Littré's footsteps, this division risks becoming canonical. Thus, in two parallel passages of Epidemics 6, where a dry cough is

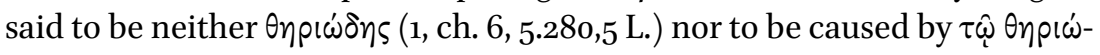
$\delta \varepsilon l(1$, ch. 11, 5.282,16 L.), the modern editors of this treatise, Daniella Manetti and Amneris Roselli, understand, as Littré did, a cough that is "not caused

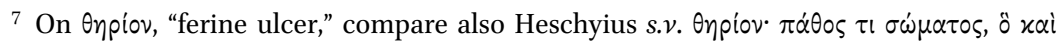
xapxivos $x \alpha \lambda \varepsilon i \tau \alpha \mathrm{l}$. On the use of Enpiov in the sense of a ferine ulcer in the Hippocratic Corpus, see H. Dönt, Die Terminologie von Geschwür, Geschwulst und Anschwellung im Corpus Hippocraticum (Vienna, 1968), p. 81. In later medical writings, the noun $\theta \eta p i \omega \mu \alpha$ replaced inpiov to mean a "ferine ulcer"; on uses of $\theta$ pi $\omega \mu \alpha$, see L.S.J. s.v.; compare also Theophrastus

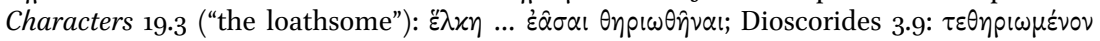

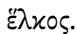

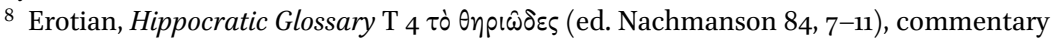
on Epidemics 2.1.3 (5.72,12 L.): "Some have said that the expression describes malign ulcers ( $\varkappa \alpha \varkappa \eta \theta \hat{\omega} \nu \dot{\varepsilon} \lambda \varkappa \hat{\omega} \nu$ ), called ferine ulcers ( $\theta \eta p i \omega \mu \alpha)$, which normally appear in autumn due to changes in the air; others have thought that it also means 'little worms', since they also appear in this period; others thought it referred to consumption." Compare Galen, Hippocratic Glossary, s.v. Anpiov (19.103,12-104, 5 K.).

9 This meaning of Enpiov is cited by Galen in his Hippocratic Glossary (19.103,12 K.): Anpiov

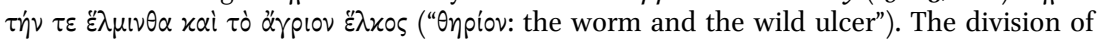

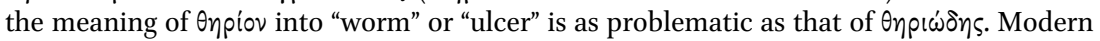
editors follow Littré (cf. the division between the meanings in J.-H. Kühn and U. Fleischer, Index hippocraticus (Gottingae, 1986), s.v. Enpiov 1, 2 spec. vermes intestini six uses and II, n. path. one use) in giving the meaning of ulcer in the passage of Places in Man c. 29; some scholars before Littré interpreted the use of Anpiov in Coan Prenotions $45^{8}$ and 459 (lientery with $\theta_{\eta}(\alpha)$ as "worms," and others as "ferine ulcers"; cf. note ad loc. by Littré 5.686. On the possible relationship between lientery and intestinal ulcers, see Aretaeus, The Causes and Signs of Chronic Diseases, 2.10, ed. Hude ${ }^{2} 79,15^{-30}$.

10 He adopted the meaning of "caused by worms" in all the passages of Epidemics 2-4-6 and in a passage of Coan Prenotions (c. 613), and the meaning of "wild" in the other passages of Coan Prenotions and in Prorrhetic 1. 


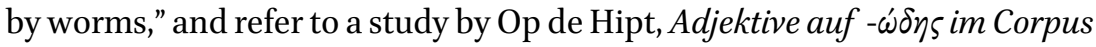
Hippocraticum (Hamburg, 1972), pp. 71-74, which interprets these two passages of Epidemics 6.1, ch. 6 and 11, in the same way as Littré. Thus, Littré is at the centre of a type of vulgate of the modern interpretation of Onpicions in the Hippocratic Corpus. However, once we remove Littré from the equation, its origin is far from clear. In the sixteenth century, Cornarius attributed to Onpísons the meaning ferinus in all the eleven passages of the Corpus where it is used. Going back even further to Erotian's and Galen's explanations of this term preserved from Antiquity, we are struck by the contrast between the unanimity of modern interpretations compared with the richness and diversity of the surviving interpretations of this word, which was judged to be obscure. The interpretation adopted by modern translators is precisely that which was criticised by the ancients. Thus, Galen, in his Commentary on Hippocrates' Epidemics 6, does not adopt the interpretation chosen by modern commentators concerning the cough, but instead strongly criticises it. Here is what he says:"1 "Some say that when the worms ( $\left.\varepsilon^{\prime} \lambda \mu \nu \nu \theta \varepsilon \varsigma\right)$ settle at the mouth of the stomach, this causes a cough, but they cannot demonstrate this, neither by reason nor by experience." Galen prefers to give Enpićons the meaning of $x \alpha x \circ$ ' $\theta_{\eta}$; thus, for him it refers to a 'bad cough'. Galen's interpretation, adopted by Cornarius, seems preferable to modern interpretations, not only because it appears more coherent to the semantic field of Onpísons

11 Galen, Commentary on Hippocrates' Epidemics 6, ed. Wenkebach/Pfaff CMG V, 10, 2, 2, p. 89. In his interesting commentary on this passage of Epidemics 6, Galen presents all the interpretations proposed for the meaning of $\theta \eta p$ particular meanings: a) consumption, when the nails are curved like those of wild beasts; b) ferine ulcer $(\theta \eta p i \omega \mu \alpha)$ in the lung; c) worms that collect in the mouth of the stomach. This passage sheds light on the explanations that he gives in his Hippocratic Glossary, s.v. Onpiov (19.103,12 ff. K.). Conversely, when he comments on the passage in Epidemics 2.1, ch. 3, where it is said that above all in autumn the $\theta \eta p$ Hippocrates' Epidemics 2, ed. Wenkebach-Pfaff, CMG V 10, 1, p. 16o), he chooses, amongst the interpretations already proposed (leprosy, so-called from the name of the elephant which is a threatening and vicious animal; melancholy, which renders the character of sick people resembling that of wild animals; cancer, which owes its name to a vicious creature; intestinal worms), that of intestinal worms. This is because Galen believes cardialgia to be a pain of the mouth of the stomach, which is caused by the increase of intestinal worms; compare Erotian's gloss of this passage quoted in footnote 8. It is surprising that Galen does not mention the general meaning of $x \alpha x \circ \eta \eta \eta\rceil s$ in this passage. When he returns in his commentary on Epidemics 6 to this relationship between autumn and $\theta \eta p \omega \omega \delta \eta$ s, in a passage parallel to Epidemics 6.1, ch. 11, he not only highlights the general meaning of $x \alpha x \circ \eta \theta_{\eta}$, but he does not choose between the various interpretations (worms, elephantiasis, cancer, phtisis), all of which he judges to be possible. Is this a sign of a development in Galen's interpretation, which becomes less analytical from one commentary to another? The interpretation of the general meaning of $x \alpha x \operatorname{ri}^{\prime} \eta \mathrm{s}$ appears to be that of Aretaeus: see infra, no. 14. 
and in the meanings that are attached to it, but also because it works better in certain passages of the Corpus. I would just like to add a clarification to

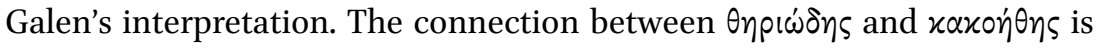
sound, but the two terms are not synonymous, since there is a difference of

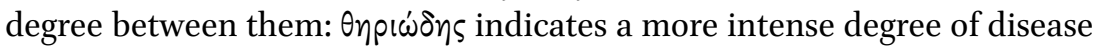

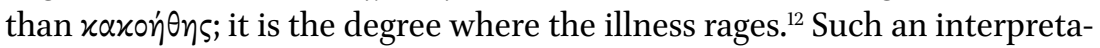
tion allows us better to account for the Coan Prenotions 613 (5.726,13-17 L.). Here is the translation:

If, when the stomach is wet, painful swellings occur, the case is bad (xaxóv); but if, whilst the stomach is narrowed, without anything new happening, these swellings quickly rupture, the affliction is worse (xai xaxon $\theta \dot{\varepsilon} \sigma \tau \varepsilon p o v)$; and if on top of that vomiting occurs, the case is even worse and wild ( $\pi$ ovnp $\dot{\alpha}$

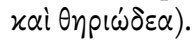

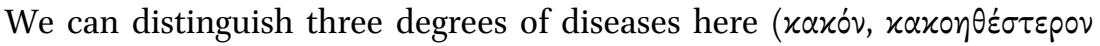
and $\theta \eta p(\omega \dot{\delta} \varepsilon \alpha)$, of which the most intense is $\theta \eta p เ \omega^{\prime} \delta \varepsilon \alpha$. Littré's interpretation, who understands the vomiting to be caused by worms, does not seem to capture the sense of an ascending scale that underlies this passage in Coan Prenotions. ${ }^{13}$ Thus, the problem of the different meanings of Onpicions in the Hippocratic Corpus is far from being definitively resolved. Even if we

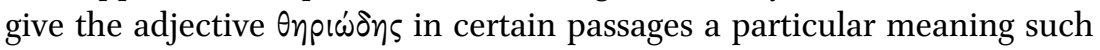
as 'caused by worms', this still does not exclude the possibility that the connotation of 'wild', 'feral' remains present. In any case, we cannot accept Littré's choice without a critical re-examination that incorporates both the history of the various interpretations ${ }^{14}$ and the history of the language.

12 Galen is not the only commentator to have made this connection; one may compare

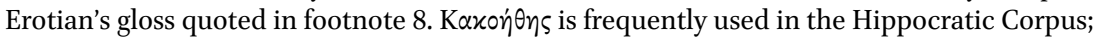
see J.-H. Kühn and U. Fleischer, Index Hippocraticus, Fasc. II (Göttingen, 1987), s.v., p. $411 \mathrm{ff.}$ This adjective, which is usually applied to living beings, bears witness, like $\theta$ n representation of disease known as a dangerous living being with malicious intent towards the patient.

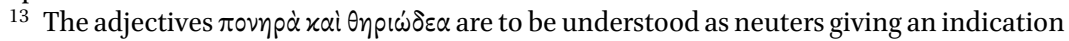

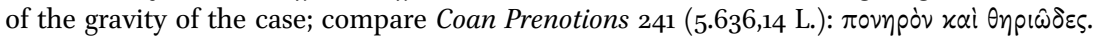
Fuchs (Hippokrates. Sämtliche Werke, vol. II (Munich, 1897), p. 95) interprets the syntax correctly when he translates: "Wenn Erbrechen hinzukommt, ist das schlimm und deutet auf Tobsuchtanfälle," which renders the sense of progression well; however, his translation

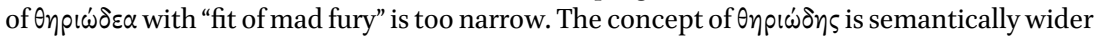
than this.

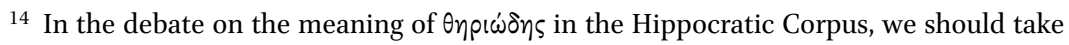
into account the testimony of a first-century AD doctor, Aretaeus of Cappadocia, who was an

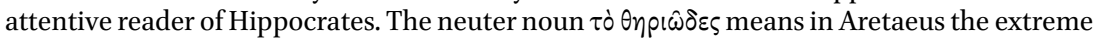
degree obtained by a disease that becomes wild. Thus, in The Causes and Signs of Acute 
It is not my intention to end the debate on the different interpretations of the adjective $\theta \eta p i \omega \delta \eta s$ in the Hippocratic Corpus, but rather to reopen it by highlighting that this ambiguous use of Onpı́์ ns in the Hippocratic Corpus finds a parallel in tragedy with the use of an adjective belonging to the same family, हैvOnpos_ something which to my knowledge has not been observed before. This adjective, which describes Philoctetes' diseased foot, has given rise to a similar variety of interpretations. In the first stasimon of Sophocles' Philoctetes in verses 677-699, the choir, full of compassion but also admiration for the hero who managed to survive his infliction for so long without the help of a doctor, exclaims: "there was no one to lessen with soothing herbs the seething blood when it seized him, which oozed from the ulcers of his ह่vधnpous foot." Mazon translated this as "with his foot swarming with vermin," whilst Kamerbeek understands "his foot inhabited by the wild beast," i.e. "by disease." ${ }^{15}$ Mazon's interpretation, which appears the most rational and realistic, finds support in Aeschylus' Agamemnon, line 562, where the messenger, recalling on his return to his homeland the difficult life of the expeditionary force to Troy, says that the dew left the hairs of their blankets हैvOnpov, 'full of vermin'. ${ }^{16}$ However, Kamerbeek's interpretation, apart from

Diseases 2.8, 7 (ed. Hude ${ }^{2}, 29,24$ ), Aretaeus, discussing acute disease of the vena cava, notes that it resembles a form of causus because, like causus, "in autumn it takes on a wild form"

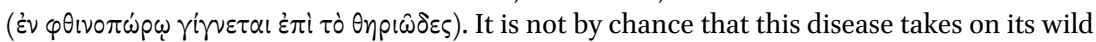
form in the autumn, since we read elsewhere in Aretaeus, in The Causes and Signs of Chronic Diseases 1.14.5 (ed. Hude ${ }^{2} 57,3$ ), concerning the influence of the seasons on disease of the

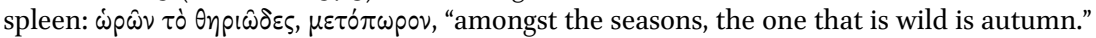
This relationship established by Aretaeus between the wild character of a disease and the autumn, which is a wild season, inevitably recalls the two parallel passages of Epidemics

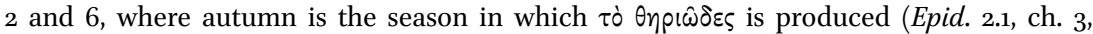

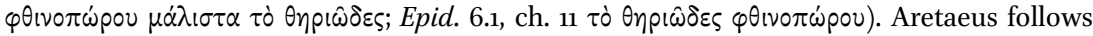
Hippocrates here and it is clear that in the Hippocratic model, he understands $\tau \dot{0} \theta \eta p$ the general meaning of the "wild character" of the disease, and not in the particular meaning of "intestinal worms," as Littré and modern commentators understood it. Aretaeus also says, in his discussion of epilepsy, that the disease takes on a wild character during crises (The

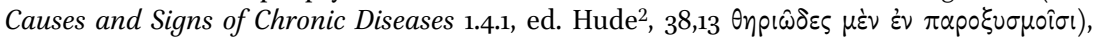

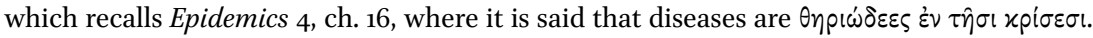
Should we understand in this last passage, along with Littré, that the patients "have worms" in crises (compare Pronostic ch. 11, 2.136,7-9 L. = Alexanderson 206,13 ff.), or that the disease acquires, during the crisis, a wild character that is demonstrated by the 'savage' behaviour of the patients?

15 A. Dain and P. Mazon, Sophocle III, (C.U.F.) (Paris, 196o), p. 35; J.-C. Kamerbeek, The Plays of Sophocles VI(The Philoctetes) (Leiden, 1980), p. 107, who refers to his very illuminating study on devouring disease in the Philoctetes entitled "Sophoclea II," which appeared in Mnemosyne, Fourth Series, Vol. 1 (1948), 198-204.

16 The translation is taken from P. Mazon, Eschyle II, (C.U.F.) (Paris, 1949), p. 30. On the meaning of हैv $\theta$ n 
being coherent with the representation of disease compared to a wild beast that we find throughout Philoctetes, accurately accounts for the metaphors in this passage. Indeed, the verb used for the treatment, $\varkappa \alpha \tau \varepsilon v \vee \alpha \dot{\alpha} \omega(697)$, recalls the image of a wild animal which is put to sleep by making him sleep

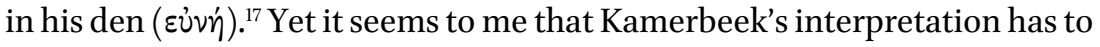
be enriched by a comparison with the Hippocratic Corpus: once we realise that also in the technical medical writings, ulcers can become wild and that a wild ulcer can be called $\theta$ npiov, and once we note that the adjective हैं $\theta$ npos in Philoctetes is used next to the word $\dot{\varepsilon} \lambda x \varepsilon^{\prime} \omega \nu$, ulcers, it becomes clear that the poetic vocabulary of Sophocles can describe, beyond the metaphor of a wild beast, a clear medical reality, that of the wild ulcer devouring the foot on which it is found..$^{18}$

Since disease is or can become wild like an animal, it acts like a wild animal that tears apart and then devours its victim. Disease devours and the diseased patient is devoured. We find this representation of the action of the disease not only in tragedy, but also in the Hippocratic Corpus.

In tragedy, the themes of devouring and wild disease are closely related. In Aeschylus and Sophocles, this connection is constant: in every case where disease is described as wild, its action is expressed in terms of devouring. In Aeschylus' Choephori, the connection is immediate and the metaphor is evident: the "ulcers with a wild bite," with which Apollo threatened Orestes, devour (281, $\dot{\varepsilon} \xi \dot{\xi} \tilde{\sigma} \sigma 0 v \tau \alpha)$. Likewise in Sophocles, the two diseases that are

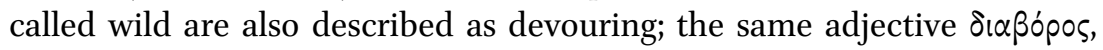
related to $\beta ı \beta \rho \omega \sigma \kappa \omega$, 'to devour', is used to describe Heracles' disease in Trachiniae (1084) and Philoctetes' disease in the eponymous tragedy (7). Euripides also recognises the devouring character of disease: in his Medea, written in 431, the poisoned robe that Medea gives to her rival, Jason's new wife, devours the flesh of its victim (1189, हैं $\alpha \pi \tau o v ~ \sigma \alpha \dot{\alpha} x \alpha \alpha)$, just like the poisoned tunic given to Heracles by Deianeira in Sophocles ate his

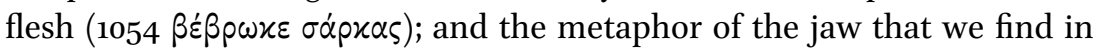
Aeschylus' Oresteia concerning the ulcers reappears in the same passage of Euripides' Medea concerning the poison's action on the flesh (1200 ff.:

tary on 1-1055 (Oxford, 1950), p. 283; see also J.-C. Kamerbeek, "Sophoclea II," quoted in the footnote above, p. $199 \mathrm{ff}$.

17 The metaphor of the wild beast in Philoctetes was noticed by scholiasts in antiquity; see

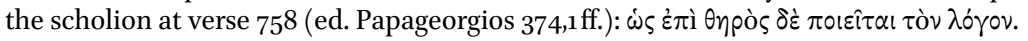

18 This interpretation is confirmed by the fact that the technical term to describe "the

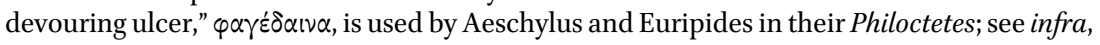
p. 9 . 
"and the flesh detached itself from the bones under the invisible bite of

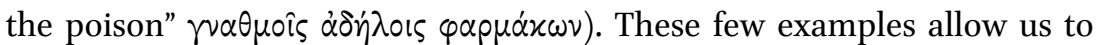
glimpse the richness of the vocabulary of devouring applied to disease in the extant tragedies. ${ }^{19}$ To complete the picture, we must consider the fragments, two of which are particularly important. We know that Aeschylus and Euripides had written about the myth of Philoctetes before Sophocles, and we can be sure that Sophocles wrote nothing novel compared with his predecessors on the theme of devouring disease, since both describe Philoctetes' disease with the term $\varphi \alpha \gamma \varepsilon \varepsilon \delta \alpha \nu \alpha$, which means etymologically "the devouring disease." ${ }^{20}$ Since this term is also attested in the Hippocratic Corpus, ${ }^{21}$ we turn now to examine how the vocabulary and the theme of devouring disease are presented in these medical writings.

It goes without saying that technical literature does not use the highest registers of a poetic style, i.e. composite adjectives or bold metaphors.

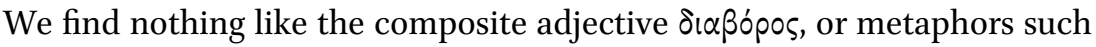
as 'wild bite'. Despite this difference, the vocabulary of devouring remains well attested in the Corpus and is comparable to tragedy. We may compare, for example, two passages where we find the term that describes devouring disease par excellence, $\varphi \alpha \gamma \varepsilon ́ \delta \alpha \iota \nu \alpha$ a fragment of Aeschylus' Philoctetes

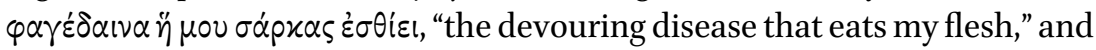

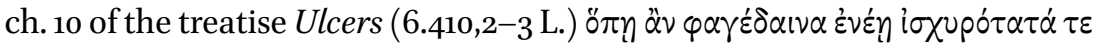

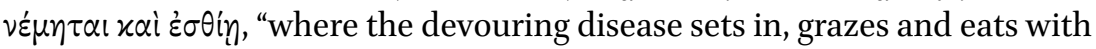
great force." For the tragic author as well as the doctor, $\varphi \alpha \gamma \varepsilon \dot{\delta} \alpha i v \alpha$ refers to the same nosologic reality: a phagadenic ulcer, or one that devours deeply. ${ }^{22}$

19 All the major sets of related terms meaning "to eat" or "to devour" can be found here: the two roots that serve to form the suppletive paradigm of the verb meaning "to eat" in IonianAttic, i.e. *ed- (cf. Aeschylus, Choephori, 281 ह $\xi \dot{\varepsilon} \sigma \theta \omega)$ and * $\varphi \alpha \gamma$ - (cf. Sophocles, Philoctetes,

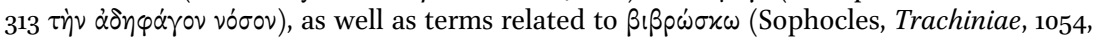

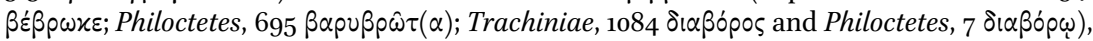

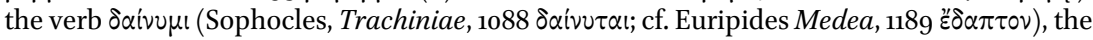

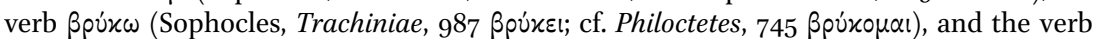

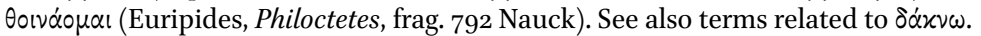

20 These two fragments were preserved by Aristotle in his Poetics 1458b22-25 (Frag. Aeschylus 253 Radt, and Euripides 792 Nauck).

21 The affliction called $\varphi \alpha \gamma \varepsilon \delta \alpha \iota \nu \alpha$ is attested four times in the Hippocratic Corpus: Airs, Waters, Places, ch. 10, 2.48,9 L. (= Diller 50,11), Epidemics 6.3, ch. 23, 5.304,3 L. (= ManettiRoselli 74,2-4); Humours, ch. 20, 5.500,8ff. L.; Ulcers, ch. 10, 6.410,2-3 L. The derived verb $\varphi \alpha \gamma \varepsilon \delta \alpha \iota o^{\circ} \mu \alpha \mathrm{l}$ is attested twice: Epidemics 4, ch. 19, 5.156,4 L. and Epidemics 5, ch. 44, 5.234,1 L.

22 In his treatise On Tumours contrary to Nature (7.727,7-9 K.), Galen contrasts the phagedenic ulcer $(\dot{\eta} \varphi \alpha \gamma \varepsilon \dot{\varepsilon} \alpha \imath \alpha)$, which attacks both the skin and the parts inside, with 
It is remarkable that both the author of this technical work and the tragedian recognise the etymological meaning of the term, since both use the

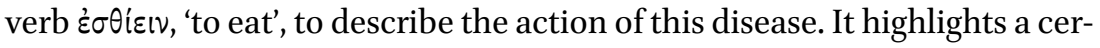
tain paradox: in the example of the Hippocratic Corpus, the vocabulary of devouring applied to disease is richer than that of tragedy, since the doctor uses the verb $\nu \varepsilon ́ \mu \varepsilon \sigma \theta \alpha$, 'to graze', as well as the verb $\varepsilon^{\sigma} \sigma \theta^{\prime} \varepsilon เ \nu .{ }^{23}$ Thus, although

herpes that grazes only on the surface. On ancient uses of $\varphi \alpha \gamma \varepsilon \dot{\delta} \alpha$ lv $\alpha$ outside Aeschylus and Hippocrates in the fifth century, see Democritus D.K. 68 B 281 (the $\varphi \alpha \gamma \varepsilon \delta \delta$ iv $\alpha$ is the most formidable form of ulcer) and Euripides frag. 792 Nauck, and in the fourth century the iamata of Epidaurus no. 66 (ed. Herzog, 32 C 134) and Demosthenes, Against Aristogiton 1, ch. 95 (ed. G. Mathieu, Plaidoyers politiques IV, (C.U.F.) (Paris, 1947), p. 169). This technical term continued to be used in Greek medicine during the Roman period; see, for example, outside Galen, Aretaeus, The Causes and Signs of Chronic Diseases 2, ch. 11 (ed. Hude 2 , 81,14). It was the object of definitions or glosses; see [Galen] Medical Definitions, 19.443,3 ff. K. (phagedaina is an ulcer that devours adjacent and nearby parts of the body); Pollux, Onomasticon 4 (Phagedaina: ulceration that extends to the bone, which devours rapidly with inflammation,

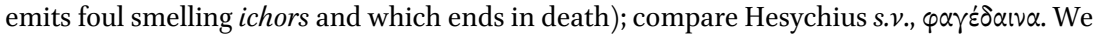
note that the term later took on the meaning of bulimia; see [Galen] Medical Definitions, 19.419,3-7 K.; compare Caelius Aurelianus, Chronic Diseases 3.3, ed. Drabkin, pp. 738-740. I owe this last reference to Mirko Grmek.

${ }^{23}$ For the vocabulary of devouring in Hippocratic pathology, see first the terms formed from the two roots ${ }^{*} e d$ and ${ }^{*} \varphi \alpha \gamma-: \varepsilon^{\prime} \sigma \theta^{i} \omega$ and its composites $\delta \varepsilon \varepsilon \sigma \theta^{\prime} i \omega$ and $\kappa \alpha \theta \varepsilon \sigma \theta^{\prime} i \omega$ in the active (Ancient Medicine, ch. 19, 1.616, 6 and 7 L. = Heiberg 49, 23 and 25: flow that grazes; Ulcers, ch. 10, 6.410,3 L.: phagedaena: Diseases of Women 1, ch. 2, 8.20,7 L.: pus; 2, ch. 122, ibid., 264, 22: flux; Glands, ch. 12, 8.566,3 L.: flux; ch. 14, ibid., 570,1: pus); ह̇ $\sigma \theta^{\prime} \omega$ and $\dot{\alpha} v \varepsilon \sigma \theta i \omega$ in the middle voice (Aphorisms 5.22, 4.540,3 L.: gnawing herpes; Epidemics 4, ch. 1, 5.144,1 L.: corrosive afflictions; ch. 20, ibid. 160,6: corrosive excrements; Use of Liquids, ch. 6, 6.134,14 L. = Joly 170,18: gnawing herpes; Ulcers, ch. 3, 6.404,14 L.: devouring and serpiginous ulcers, and ch. 10, ibid., 410,2: gnawing ulcers); $\dot{\varepsilon} \sigma \theta^{\prime} \omega$ and its composite $\delta\llcorner\varepsilon \sigma \theta i \omega$ in the passive voice (Epidemics 4, ch. 19, 5.156,12 L.: eroded tooth; Affections, ch. 4, 6.212,22 L. = Jouanna Archéologie, 268,17: eroded teeth; The Sacred Disease, ch. 11, 6.382,13 L. = Grensemann 78,23: eroded brain); $\varphi \alpha \gamma \varepsilon \delta \alpha i v \alpha$ and $\varphi \alpha \gamma \varepsilon \delta \alpha$ vóo $\mu \alpha$ (references are given in footnote 21); see further the terms

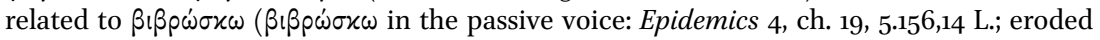
tooth; ch. 25, ibid., 168,18: teeth; ch. 52, ibid., 192,8 and 9: teeth; Affections, ch. 4, 6.212,18 and

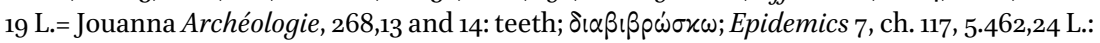
eroded intestine and fistula; Fistulas, ch. 3, 6.45o, 2 L.: part of the eroded rectum; ch. 4, ibid., 450,26; ch. 5, ibid., 452,16; Diseases 2, ch. 23, 7.38,14 and 16 L. = Jouanna 158,5 and 7: eroded

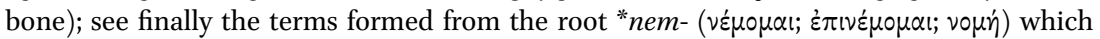
are studied below. As in tragedy (see footnote 19), we should add terms related to $\delta \alpha \dot{x} v \omega$. On the connection between $\delta \dot{\alpha} x v \omega$ and $\dot{\varepsilon} \sigma \theta^{\prime} \omega$, see for example Diseases of Women 2, ch. 122, 8.264,22 L.: flux that bites ( $\delta \dot{\alpha} x v \varepsilon l)$ and devours ( $\dot{\varepsilon}^{\prime} \sigma(\varepsilon \iota)$. The vocabulary of devouring applied to pathology continued to be used in medical writing of the Roman period, and is enriched with the use of nouns unknown in the Hippocratic Corpus, such as $\delta i \alpha \beta p \omega \sigma \varsigma \varsigma$ "the action of devouring" (see in particular Aretaeus, The Causes and Signs of Chronic Diseases 2.11, quoted

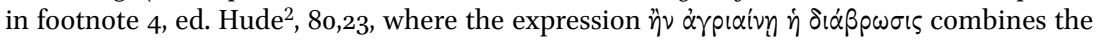
two notions of wild and devouring) and $v \varepsilon \dot{\mu} \mu \sigma \iota \varsigma$, "action of grazing" (Aretaeus, The Treatment of Acute Diseases, 1.9.1, ed. Hude ${ }^{2}$, 113,9). 
the Hippocratic doctor envisages the affliction called $\varphi \alpha \gamma \varepsilon \dot{\delta} \alpha$ iv $\alpha$ from a rational point of view, his vocabulary preserves here an archaic conception of

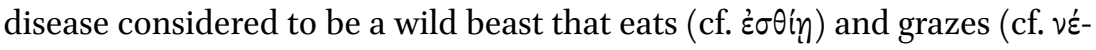
$\mu \eta \tau \alpha \iota)$.

A more in-depth study of these two verbs, which characterise the action of devouring ulcers in the Hippocratic Corpus, shows that the vocabulary of devouring preserves a force and coherence in the technical language of doctors that modern scholars tend to overlook, as was the case for the vocabulary associated with the wild. I will not discuss here the problem of the existence of the middle participle of $\dot{\varepsilon} \sigma \theta^{i} \omega$, ignored by LSJ and certain modern editors, but well attested in the Hippocratic Corpus regarding devouring ulcers, since I discussed this topic in a paper at the VII Congreso Español de Estudios Clásicos in Madrid. ${ }^{24}$ Instead, I will turn to the use of

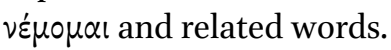

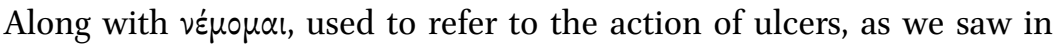
ch. 10 of Ulcers, there is a further name of disease belonging to the same family, the noun $v o \mu$, which is found in the plural in four passages of the Hippocratic Corpus (Prorrhetic 2, ch. 12 and 13, Ulcers ch. 18 and Dentition ch. 20). In the same way that the disease called $\varphi \alpha \gamma \varepsilon \dot{\delta} \alpha i v \alpha$ is the disease that eats ( $\varphi \alpha \gamma \varepsilon i v)$, the disease called $\nu$ on $\eta^{\prime}$ is essentially the disease that

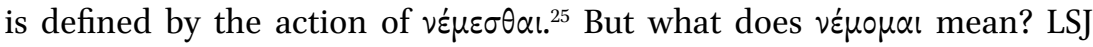
translates this word, used concerning ulcers, as 'to spread', and translates the noun vouxi as "spreading ulcers"; thus, any meaning of "to graze" or "to feed on" has disappeared from this modern interpretation. ${ }^{26}$ However, if we look at earlier interpretations, we observe that Littré, whilst being less consistent, translates two of the four occurrences of vopaí as "gnawing ulcers," thus trying to preserve the etymological sense. If we go back even further to the sixteenth century, Foes, in his Oeconomia Hippocratis s.v.,

${ }^{24}$ J. Jouanna, "La maladie dévorante: existe-t-il un présent moyen de “èsthio'?," in Universidad Complutense (ed.), Actas del VII Congreso Español de Estudios Clásicos, Vol. I (Madrid, 1989), pp. 199-208.

${ }^{25}$ The connection of the name of the disease $v o \mu \eta$ with the middle voice $v \varepsilon \varepsilon \varepsilon \sigma \theta \alpha \mathrm{l}$ is found as early as in Galen: see De simplicium medicamentorum temperamentis ac facultatibus 8, ch. 4

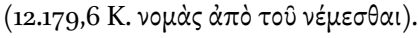

${ }^{26}$ I will not tackle here the problem of determining how the etymological meaning of

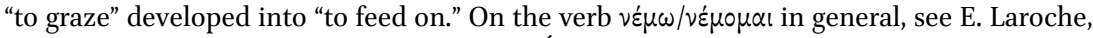
Histoire de la racine *nem- en grec ancien (Études et commentaires 6) (Paris, 1949) and F. Heinimann, Nomos und Physis. Herkunft und Bedeutung einer Antithese im griechischen Denken des 5. Jahrhunderts, (Schweizerische Beiträge zur Altertumswissenschaft 1) (Basel, 1945), p. $59 \mathrm{ff}$. 


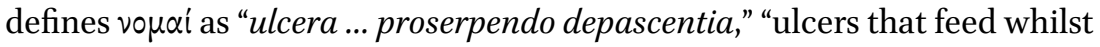
spreading." This definition seems excellent, because it subordinates the secondary sense of "to spread" to the etymological sense of "to graze." Indeed, we would be wrong to remove the original meaning of $\nu \varepsilon \dot{\mu} \mu \mu \alpha$ from its technical uses when it concerns ulcers, or an affliction more generally. It is clear, for example, that in chapter 10 of Ulcers, which has served as

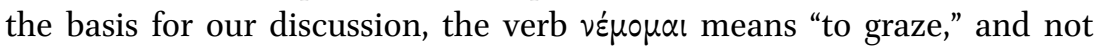
the secondary sense of "to spread," not only because of the vocabulary of devouring that accompanies it, but above all because it is modified by the intensifying adverb i $\sigma$ \ $p o ́ \tau \alpha \tau \alpha$. The doctor fears the destructive character of the ulcer that grazes. Thus, the author of Prorrhetic 2, ch. 13 (9.36,6 ff. L.) says that within the category of ulcers which he calls $\nu$ o $\mu \alpha i$, or rather $\varepsilon \lambda x \varepsilon \alpha$ ö $\sigma \alpha$ $\nu \varepsilon \dot{\mu} \varepsilon \tau \alpha$ l, the most dangerous are those in which the principles of corruption

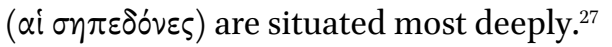

Of course, the meaning of "to graze" does not exclude the secondary sense of "to spread"; since the action of grazing implies that the animal spreads and that the eaten surface is extended, we can understand how the secondary sense of "to spread" was able to develop and even erase, in certain contexts, the original meaning. Even within the Hippocratic Corpus, we find an example where the original meaning of $\nu \varepsilon \dot{\mu} \mu \mu \alpha$ เ is erased, concerning the anatomy of the route of the blood vessels. ${ }^{28}$ However, there are two principal uses of the word in which the first meaning was retained throughout the history of Greek, and these concern the two most formidable destructive forces:

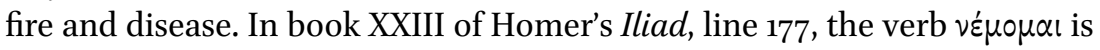
used alongside the verb $\varepsilon \sigma \theta i \omega(181)$ to describe the fire of the funeral pyre

27 H. Dönt, Die Terminologie von Geschwür, Geschwulst und Anschwellung im Corpus

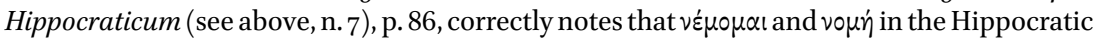
Corpus preserve their meaning of "to graze, devour"; cf. also F. Heinimann, Nomos und Physis.

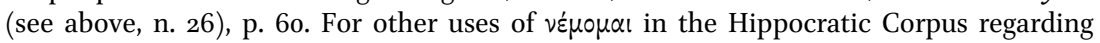

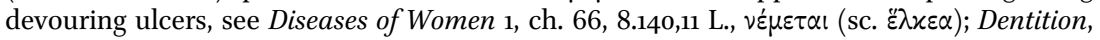

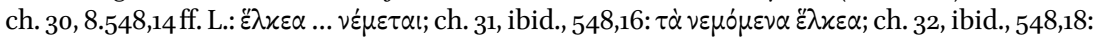

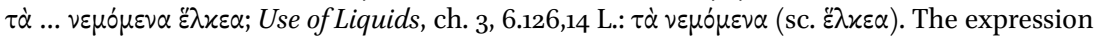

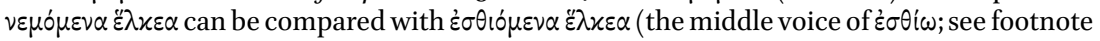
23).

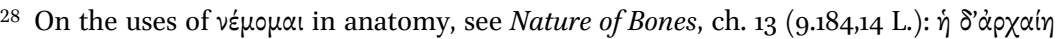
$\varphi \lambda \dot{\varepsilon} \psi \dot{\eta} \nu \varepsilon \mu \rho \mu \varepsilon \dot{\varepsilon} \eta \pi \alpha \rho \dot{\alpha} \tau \dot{\eta} \nu \alpha \ddot{x} \alpha \nu \theta \alpha \nu$, "the primitive vessel, which extends along the spine"; cf. also ibid., ch. 16, ch. 17 and ch. 18. cf. also í to determine the fundamental meaning that explains this derived use: does it refer to distribution or to grazing? It is possible that the vessel was known primitively as a living being

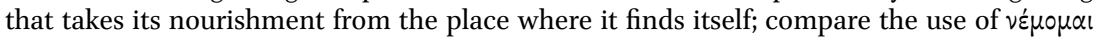
with regard to glands in the treatise Glands, ch. 5, 8.560,9 L. 
that devours Patroclus' body. This representation of devouring fire is still very much alive in the fifth century. For example, in Aeschylus' Choephori, the metaphor of biting is used not only concerning diseases, as we have seen, but also concerning the ritual fire that devours the corpse. ${ }^{29}$ The first

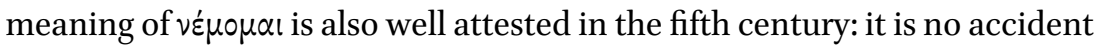

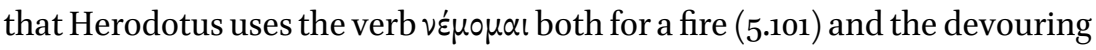
ulcer of Atossa (3.133). ${ }^{30}$

The disease's action may even be compared to that of a fire, to the extent that it manifests itself in the form of an inflammation. We should not forget that the term $\pi \hat{\rho} \rho$ can mean both fever and fire. This representation of disease allows us to understand a passage from Epidemics 3, where $\dot{\varepsilon} \pi v \varepsilon^{\prime} \mu \rho \mu \alpha \iota$ is used. In the second annual constitution which it describes (Epidemics 3.2, 4, 3.72,3-5 L.), the author says that erysipelas occurred:

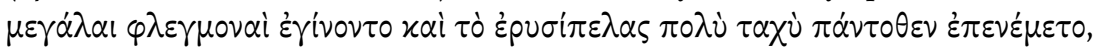
"great inflammations followed and erysipelas very quickly $\dot{\tau} \pi \varepsilon \varepsilon \dot{\varepsilon} \mu \varepsilon \tau 0$ all over."

How should we translate this verb? Following LSJ, the Index Hippocraticus translated it as "procedo," 'to proceed'. ${ }^{31}$ This translation obscures the deeper meaning of the passage. Erysipelas, which is already a disease that is etymologically inflammatory (literally, 'a disease that makes the skin redden'), and which, moreover, is accompanied here by large inflammations, is a disease that devours everything, like a violent fire, and progresses quickly. Littré translated this more accurately than modern editions, when he said: "rapidly the erysipelas extends its ravages all over." Indeed, to understand

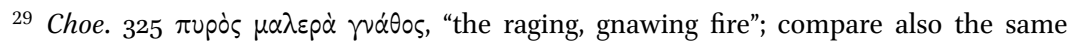

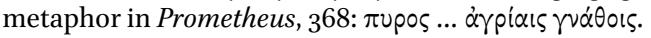

30 The relationship between the two passages of Herodotus was noted by H. Stein,

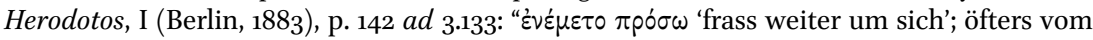
Freuer (V, 101, 9)." However, the translation of E. Legrand (Hérodote III, (C.U.F) (Paris, 2003), p. 167) "(l'abcès) gagna de proche en proche" is too weak. First of all, Atossa's abscess, once

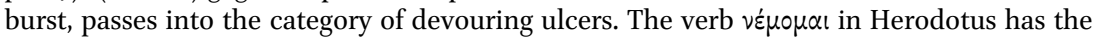
same meaning as in Prorrhetic 2, ch. 13, where it describes a category of ulcers. Even in Thucydides, the composite $\dot{\varepsilon} \pi \imath \varepsilon \dot{\varepsilon} \mu \rho \mu \alpha$ is used with reference to the Athenian 'plague' (2.54.5

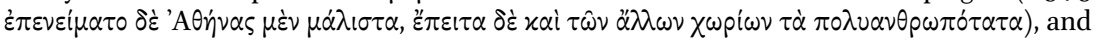
although it has a less technical meaning than in Herodotus, it preserves the idea that the plague attacks everything in its path; compare the use of $x \alpha \tau \alpha v \varepsilon$ fo $\mu \alpha$ l with regards to the 'plague' of Athens that "devours the flower of youth" (translation from Flacelière) in Plutarch,

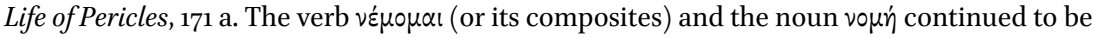
used after the Classical period for fire and disease. For example, in Diodorus of Sicily, the

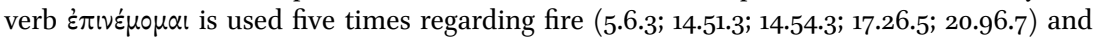
twice regarding disease $(3.29 .6 ; 12.12 .3)$.

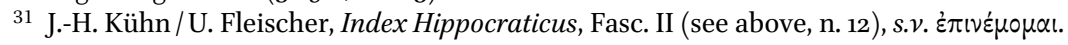




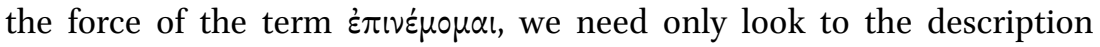
of the ravages left by the disease: "flesh, sinews and bones fell away in

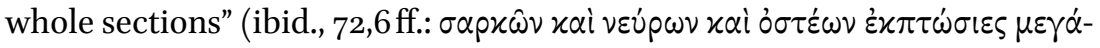
$\lambda \alpha \mathrm{l})$. Despite the restraint of technical prose, the vocabulary still forcefully describes the effects of the disease. This analysis also allows us to understand better why Galen interprets "the wild inflammation," the $\pi \hat{\rho} \rho$ ä $\gamma p$ เov of Epidemics 7, ch. 20, as erysipelas. Erysipelas is a wild affection that devours like fire or a wild beast. Returning to the comparison with tragedy, this description of erysipelas by the Hippocratic doctor in Epidemics 3 may remind us of Euripides' descriptions, in the Medea, of the effects of the poisoned gifts on the body of the married youth. It refers to devouring fire ( 1187 $\pi \alpha \mu \varphi \alpha$ you $\pi$ upós) and flesh that breaks loose from the bone under the effect

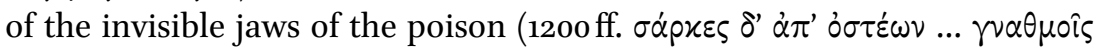

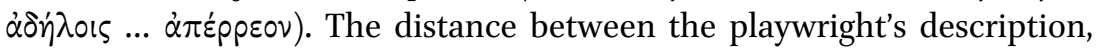
who uses pathos for amplification, and that of the scientist, who is describing a single disease amongst others, may appear large; but the image of the disease is fundamentally the same: this is a disease that, in the same way as a fire, devours the flesh, which detaches from the bone.

This comparative examination has shown that doctors in the Hippocratic Corpus preserved in their pathology a vocabulary associated with wildness and devouring, just like tragic authors. Of course, this vocabulary is not exactly the same in both genres, and its use is more limited in medicine than in tragedy. However, these are differences of degree, not of kind. What we gain from this comparison is that it shows that what can appear in tragedy as a simple poetic metaphor corresponds, in fact, to a technical usage, and that conversely the technical language of doctors preserved a metaphoric vocabulary whose original meaning risks being obscured if we have a too fragmented view of the language and a too rationalist view of the ideas.

Finally, the comparison allows us to make a contribution to the history of ideas by reconstructing the coherent intellectual representations that link the Hippocratic Corpus with Greek tragedy. Disease can, in its acute form, appear as an eruption of something wild, which threatens to devour a man's flesh like a ferocious beast, or a fire compared to a ferocious beast, and it can eventually lead to the patient's behaviour becoming like a wild beast. This representation of disease, which is exploited by the tragic authors to create fear, is also present in the Hippocratic Corpus, where fear is brought under control, because the technical language used by doctors to describe and characterise certain afflictions is inherited from a vocabulary with roots to a period before civilisation, which the Greeks of the classical period 
themselves characterised by the fear of wild animals and those described as "wild." ${ }^{32}$ Medicine is one of the arts that put an end to this 'wild' period, as the author of Ancient Medicine brilliantly shows. However, disease remains, in the Greek imagination, present as a threat of wild forces in the civilised world, forces that are both formidable and difficult to combat since they are no longer outside of man, but within man..$^{33}$

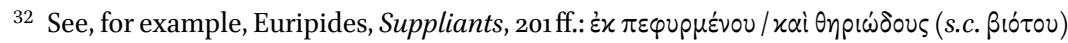

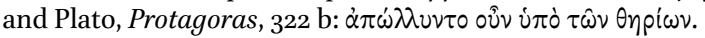

33 The idea that disease risks being an outbreak of the wild in the civilised world is clearly presented in Euripides' Orestes: the death of the mother which brought about in her son a

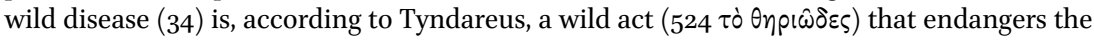
law $(523 \tau \hat{\varphi}$ vó $\mu \omega)$. Moreover, disease, considered as a wild outbreak, served as a model to show the outbreak of wild behaviour in people; see the passage in Polybius, Histories 1.81, $5^{-10}$, where he makes a comparison between bodies that are preyed on by ulcers, which "become wild" (81, $5 \dot{\alpha} \pi \circ \theta \eta p 10 \hat{\sigma} \theta \alpha \mathrm{l})$, and souls that are affected by disease, such that men end up "becoming wild" (81, $9 \dot{\alpha} \pi \circ \theta \eta \rho \iota \omega \theta \dot{\varepsilon} \tau \varepsilon \varsigma)$ and behave at the limits of human nature. 